\title{
ARCHITECTURAL HYBRIDS IN KALEIDOSCOPIC PHOTOGRAPHY
}

\author{
A B S T R A C T
}

This paper focuses on the topic that is somehow a crossroad between two fields: photography and architectural morphogenesis. The particular interest of the article is contemporary photographic tendency to explore the kaleidoscopic technique and aesthetics in relation to the architectural objects and urban environment. Paradoxically these are the photographers who investigate this special type of morphogenesis of architectural form. However some of them are architects originally. Giving attention to the historical and evolutional aspects of the kaleidoscopic image in $19^{\text {th }}$ century and kaleidoscopic photographic practices of American artist Alvin Langdon Coburn and his followers in $20^{\text {th }}$ and $21^{\text {th }}$ centuries the paper aims to analyze the potential of photography in developing the architectural form by examples of projects of Mattia Mognetti, Borbála Sütő-Nagy, Cory Stevens, Stéphane Laniray, Panos Papanagiotou, Andrey Chegin, Mohammad Domiri and those photographers who were inspired by camera work from the movie "Inception" - Ben Thomas, Kazuhiko Kawahara, Simon Gardiner, Nickolas Kennedy Sitton. 
"Make picture of kaleidoscope".

William H.Fox Talbot

(ms. Note dated February 18, 1839)

"In symmetry there is a balance; in balance there is harmony; in harmony, equilibrium".

David Kalish, Kaleidoscope artist

Kaleidoscope is an optical plaything: it's body slides, giving birth for spontaneous multi-colored patterns. Kaleidoscope discovered new horizons of human vision - fragmented, fractioned. Discovered the opportunity to observe the images that constantly mutate, sprouting one into the other, while being ordered and chaotic at the same time. Invented in 1816 by Sir David Brewster, it immediately got a lot of fans. With the course of time it's construction developed and gave birth to several "relatives" of kaleidoscope - teleidoscope, wheel scope, marble scope, cell scope, projection scope and so on. All of them are magic toys promising to surprise the viewer and inspire him with a sense of wonder.

Ordered chaos seems to be the main character of the kaleidoscopic image. The order we find in the symmetric structure of the figure: a basic pattern within it always repeats constant times (three, six - depends on the structure of the prism) and always equally. Chaotic is all the rest: colorful elements within the fragment are mated with each other freely, guided by chance, creating unpredictable and undirected motif.

Being a handmade and human invented device, kaleidoscope has kind of prototypes in nature. Some living organisms (Botryllus marionis, Aurelia insulinda, some Radiolarias, etc) in the process of transferring them to the planar views in certain projections exhibit the ability to form analogues of kaleidoscopic images. That resemblance we might observe in visual searches of the German biologist Ernst Haeckel. In his drawings he was focused so much on ocean creatures ${ }^{1}$. Besides the iris of animal's and human's eye (although being not so fragmented, but more homogeneous), some crystals demonstrate kaleidoscope-like structures. 


\section{KALEIDOSCOPE: FROM A MAGIC TOY TO THE PHOTOGRAPHY TECHNIQUE AND THE ART FORM}

Overcoming its plaything status kaleidoscope became a serious instrument in the hands of artists, filmakers, later - new media artists, sculptors. It provides huge opportunities in experimenting with form, structure, volume. Photographers began to simulate the effect of this intricate instrument in the early $20^{\text {th }}$ century although as far back as 1839 one of the pioneers of photography William H.Fox Talbot has noticed: "Make picture of kaleidoscope"2. In 1917 American artist Alvin Langdon Coburn practiced with close up subjects shooting them through the prism of three mirror surfaces. He got black and white abstractions with spectacular play of light and shadow as if they have been composed of fragments of mirrors. Applying the same method to the portrait photography (so he portrayed, for example, the poet Ezra Pound) Coburn created less abstract and more substantive pictures, something like collages assembled from multiple repetition of elements in different positions - vertical, horizontal, with a deviation of the diagonal. This type of photography he called Vortograph.

The name Vortograph refers to the name of the art movement originated in the environment of British artists and then became international, Vorticism. Inspired by Cubism, participants of this movement depicted objects and human figures as compositions of abstract angular figures's conglomerations. Alvin Langdon Coburn's Vortograph experiments visually are very similar to Vorticist's pictures. By the way Vortograph consideres to be the first abstract type of photographic image ${ }^{3}$. That means that besides being the inventor of kaleidoscopic photography Coburn is one of the photo abstraction's pioneers: his spectacular works follow the avant-garde artistic spirit of the early $20^{\text {th }}$ century. By the way nonrandomly he chose Ezra Pound as a model for his kaleidoscopic portraits as Pound was the godfather of Vorticism. The Vorticists were actually named by Pound - after the image of a vortex, that "point in the cyclone where energy cuts into space and imparts form to it..."4. Pound's service to Vorticism was "as appreciable as his theoretical and literary merit as such".

Later kaleidoscopic technique has been developed by initiatives of famous and not so much photographers. $20^{\text {th }}$ century is marked by positioning as the kaleidoscopic subjects nature elements (for example, Horst P. Horst made a step out of fashion line and in 1946 published "Patterns of nature" researching the visual structure of plants, shells, butterfly wings) or human body ("Wegee's Creative Camera", 1959, and others). 


\section{ARCHITECTURE AND KALEIDOSCOPIC VISION IN 21 $1^{\text {ST }}$ CENTURY}

In 2000-2010s, driven by the development of digital photographic techniques and software for image processing, several photographic projects focused on kaleidoscoping architecture originated independently of each other marking the new emerging tendency. Consider some of them.

\section{Mattia Mognetti. "Istigkeit"}

Italian photographer Mattia Mognetti with his black and white project "Istigkeit" (started 2011) grows something like architectural crystals placing them into the space of weightlessness, nowhere. By deformating the original shape of the buildings the author violences the basic principles of gravity: new born architectural objects are floating in the vacuum, visually reinforcing by totally black background. They are ready to move and rotate in any direction and are not tied to the Earth, space has lost its predominance. No basis, no foothold - objects are hovering, self-sufficient. Mognetti partly creates the perfect likeness of kaleidoscopic images, but more often uses the principle of the kaleidoscope and improvises on its basis. He calls his project "(de) construction experiment" and it is in fact: experiment with form, volume, texture. "I focused on emptiness and fullness interacting with space and time" - Mognetti brings a philosophical note to his concept ${ }^{6}$. As one of the epigraphs he takes words of the artist Maurits Cornelis Escher who is famous by his graphic impossible worlds: "I can not keep from fooling around with our irrefutable certainties. It is, for example, a pleasure knowingly to mix up two and three dimensionalities, flat and spatial, and to make fun of gravity". Making fun of gravity is essential for Mognetti as well as endeavors to "grow" architecture capable of volume coupling and spatial discontinuities, previously

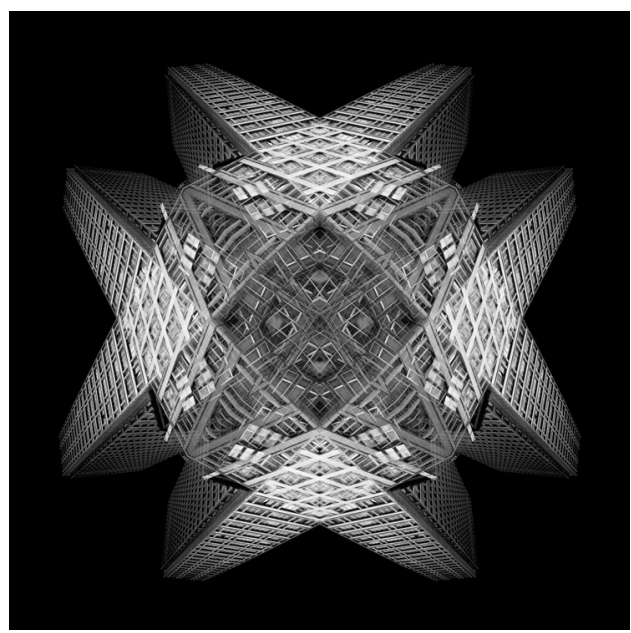


impossible. Besides Escher he refers to "Star Wars" and Rorschach's test as well'. "I also felt this project related to my academic studies in psychology and neuroscience, which gave me some skills useful to reach my purposes, speaking about perception and visual communication. I was deeply intrigued by the surreal touch of the final images, suspended in space and time in somekind of tension between reality and utopia. Meaning is not given, it is in the observer, whose eyes could recognize something idiosincratic"».

\section{Borbá7a Süto-Nagy. "Kaleidoscope".}

Hungarian photographer Borbála Sütő-Nagy offers her own variant of experiments with form - brutal minimalistic constructions, "built" from simple massive basic elements by rhyming and matching them ${ }^{9}$. The texture of these basic elements is mostly neutral, unobtrusive, allowing the view to focus on the form by it self. New hybrids are geographically unlinked as they are too abstract to be recognized as some parts of a real object which is BMW Welt building. "The kaleidoscope project is a kind of continuous project for me. Maybe it started with drawing mandalas when I was 15 years old ${ }^{10}$. Maybe my first impress was that as a child I had a kaleidoscope toy, and I was so amazed how the little things in it made a new picture by turning it. And after many years I remembered this optical effect when I edited my photographs by mirroring and duplicating them. Firstly it was only a "playing around" with only one photo what it could be. I am interested in possibility to create something new vision from an already existing object, and sometimes using only a little slice of that"11.

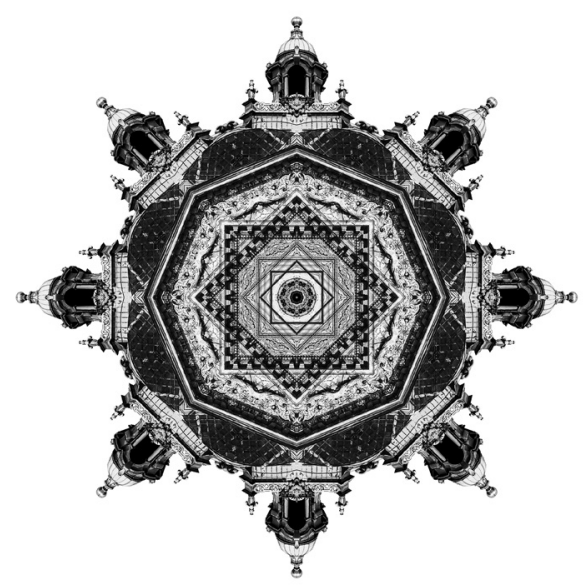


Cory Stevens. "Deconstructed. Reimagined", "Deconstructed II. A7tstadt", "Abstracted. Manipulated".

One more author as well as Mattia Mognetti announced his activity as deconstruction - Canadian photographer Cory Stevens named one of his project "Deconstructed. Reimagined" and another one "Deconstructed II. Altstadt". And it is quite a radical experience: the majority of deconstructed by him buildings in all his series, and there are three of them ${ }^{12}$, have no common with their origins whether it is Academy of Music in Munich located in a building built by the Nazis in the early 1930s, Music Academy in Stuttgart or Munich Bavarian State Chancellery. It is Munich where Stevens has found most of his objects. Deconstruction for him is a kind of architectural game that allows to refresh one's vision: "I liked the idea of being able to take a subject very typical or normal - something that maybe we do not look twice at - and re-imagine it into something that you can not help but look at ${ }^{13}$..." He is one of the most accurate adepts of the kaleidoscopic technique who succeeded in creating both planar images and images that seems to be volumetric (by means of distortions). It must have been an exact imitation of kaleidoscopic picture that allowed the author to create compositions similar to the ceiling ornaments in religious cathedrals even in such cases when he worked with the exterior of the buildings of non religious function. "These projects were inspired by the works of other contemporary photographers, artists, and designers. In specific, I was impressed by the work of Mattia Mognetti (Italy), Florian Mueller (Germany), and Benjamin Monn (Germany). The idea started as a curiosity. But because these projects have become so popular, I've been motivated to continue exploring architecture through this approach. The most intriguing part of this type of project is that you never know exactly how a piece will turn out. You may start the process with an interesting element, but how it transforms during the process is always a surprise. I am experiencing the form, not the function, exploring the geometry of the design outside of the intended context $t^{14}$."

Mohammad Domiri. "Architecture Ga77ery".

Iranian artist Mohammad Domiri traces "native", taken from architectural reality kaleidoscopic patterns, geometric ornaments of religious architecture (Ali Qapu Palace, Nasir Al-Mulk Moscque, Seyyed Moscque and others). By using the fish eye lenses Domiri broadens the frame view and composes each subject as a universe which discovers the visual shift from it's spatial context. Due to the optical strain some objects become less important while others dominant ${ }^{15}$. Volume transforms into planar view, sacral space transforms into ornamental pattern. 


\section{Stéphane Laniray. "Tokyo Architecture”.}

Stéphane Laniray from Paris in his series "Tokyo Architecture" shies away from leaving in the shot details of urban space - poles with electrical wires, trees. Nude architectural objects are not enough for him: Laniray is transforming and reinterpreting the city's texture and city space. Taking an elegant motif he mirrors it vertically and horizontally. He creates something fantasmogoric, impossible image of the city - "une poésie urban"16. And yes, "Tokyo Architecture" might be seen as a visual urban poetry, which has its own rhythms and rhymes.

\section{Panos Papanagiotou. "The MIRRORS iPhoneography Project of Hel7opanos".}

Greek visual artist Panos Papanagiotou (nickname - Hellopanos) offers his own vision on "flying" architecture and reinterpretation of urban space. He frees objects from their urban context (facades of buildings, electrical wires, lights, antennas, satellite dishes, trees, cranes), processes them with iPhone applications and turns into objects floating in the sky or in the mist-somewhere. Often they remind the Rorschach inkblots ${ }^{17}$.

Virginio Favale. "KaTeidoScape", "Space", "Buildings".

In his series "KaleidoScape" Rome based photographer Virginio Favale invites the viewer to the negative world while images from "Space" are cosmic allusions and images from "Buildings" are colorful tapestries ${ }^{18}$. The umbrella for those three series is the kaleidoscopic technique. White line on black, another one, block of lines - condensed and rarefied patterns of power transmission poles figures unique type of scape, KaleidoScape. "Space" allusion is obtained with a lot of glossy blue, green and yellow surfaces: this combination of colours flavored with radiance gives a feeling of cosmic architecture. For "Buildings" Favale has chosen rich textural surfaces (walls with advertisement billboards, objects with interesting geometric ornaments, colorful interiors), which have a potential to turn into ornamental-like compositions after kaleidoscope transformation.

\section{Andrey Chegin. "City-cross", "Escher's Space”.}

In sepia series "Escher's Space" and "City-cross" Russian master of photography Andrey Chegin uses hand-made technique of kaleidoscoping the images. He provides the lens filter with the mask which carved in a sector: one quarter, one third or fifth - on request. Then, depending on which 
part is cut off, so many shots are done: cut a quarter - do four shots. The smaller the sector the more kaleidoscopic picture becomes. "City-cross" is a series of several patchwork photographic gobelins which develope the form variations of a cross in architecture (traditionally it's an element with reach symbolic meaning). Crosses are constructed from massive domes, slender towers, columns, walls and many other architectural details and types of the buildings ${ }^{19}$. The second project, "Escher's Space" exposures photos by ones ${ }^{20}$, not in groups. Columns of Athenian Acropolis are turned into a swastika, the St. Petersburg Winter Palace, replicated four times, forms a black square and collage from Berlin TV Tower body resembles a bizarre flower. "Escher's Space" was conceived in the 1980s, after I saw the album of the artist Escher who anticipated the modern computer graphics," - Andrey Chegin explains the origin of the idea for that project. - "Escher drew on the plane architectural objects, which could not exist in reality, in volume. One example: a person climbs the ladder and as a result moves down. Even impossible to imagine how it happens. Looking through Escher's album I thought about creating things like that in photography. And in 1996 figured out how to do it”21.

\section{“INCEPTION” INSPIRED}

In a random way the author of this paper has discovered several projects with kaleidoscopic aesthetics that follow the same prototype as their originators or art critics in analysis announce which is not a kaleidoscope at all, but a movie: "Inception" (camera work - Wally Pfister). These are those projects: "Accession" by Ben Thomas, "Creatures of the City" by Kawahara Kazuhiko, "Upside Town I" and "Upside Town II" by Simon Gardiner and "Twisted" by Nicholas Kennedy Sitton. Their creators all as one were inspired by the "Inception"'s camera work and that particular episode where the transition from the real physical space to the dreaming space is shown as crashing of the city streets into scattered fragments of a curved mirror. However the methods of kaleidoscoping the image, the optical shift from a "normal" picture as well as the author's interpretation of the manipulation are different.

In "Accession" (since 2012) Ben Thomas from Australia mirrows the city vertically, stretching it, depriving it the sky and the horizon. Kaleidoscope effect is achieved in post processing. Almost all images are bird eye views: "they were shot from high vantage points being either rooftops of buildings or from a doorless helicopter"22. That gives the viewer a sense of detachment, generalized view of the city, the view that is devoid of personal affection to a particular park, courtyard, street corner. The city as an endless maze where you 
can get lost and lose yourself, then find and be found. In some cases he calls to labirints of Maurits Cornelis Escher as in "Everyone's Advice" depicting Museum d'Orsay's Hall. But his main inspirations come from Jeffrey Smart and Andreas Gursky. "Both for different reasons, Smart in relation to his use of perspective and colour and Gursky, his use of scale. The kaleidoscopic effect is a tool to deconstruct the large and complex cities we live in. This visual representation can help people think differently about architecture and space, show familiar structures in a new way that help in the appreciation of the architecture and design that we can sometimes take for granted". ${ }^{23}$

The following projects visually are very similar: Kazuhiko Kawahara's "Creatures of the City" (since 2003) and Simon Gardiner's "Upside Town I" (2011) , "Upside Town II" (2014). Both authors focus on fragments of the buildings, not specific ones, but ordinary, then multiply the chosen fragment 2, 3, 4 times digitally using such effects as repetition for axis, rotation for center and others. They are desiring to overcome three-dimentional structure of the space. New hybrids are far from the original structures, they are absolutely independent architectural objects with their own biography. Kozuhiko Kawahara from Japan (pseudonym - Palla) argues that through such manipulation he would do unremarkable architecture more lively and interesting for citizens: "They're places that no one cares about, that are almost just quietly fading away. But I'm trying to reveal the structures and systems of a city that you can't actually see"24. Kawahara's interest is converting from 3D to 2D images, which is the way of perception of the world. "Only when the $3 \mathrm{D}$ space is converted to the $2 \mathrm{D}$ image the kaleidoscopic images are appearing - I'm interested in that. I started the project from 2003. At that time I have encountered some scenes in a real world as if that were mirroring images" 25 . Simon Gardiner from Great Britain explains he has been inspired by experiments of postmodern architects from the late 1980s which were based on the idea of the fragmentary nature of the world, interest in the manipulation of the shell and the skin of architectural structures, their distortions resulting to a rather aggressive invasion of buildings in the urban space. His work Gardiner presents in a from of a manifesto as the deconstructivists $\mathrm{did}^{26}$.

San-Francisco based photographer Nickolas Kennedy Sitton in "Twisted" examines the "Inception"'s crumbling effect like it is. The author has invested sensations from a new for him urban space: he had just recently moved to San Francisco, being lost, disorienting and impressed by this city at the same time. Through his series "Twisted" he studied the process of distortion and warping.

"These photos are a result of how intriguing the concept of distortion translates 
to architecture. It creates a sense of falling into itself, like capturing a moment of demolition. I can destroy titanous steel structures with the click of a mouse and create new twisted versions of reality"27.

\section{DECONSTRUCTION AS THE KALEIDOSCOPE METHOD}

All analyzed photo projects apply the deconstruction method in one way or another. Disassembly the architecture object into components, fragments and then assembly and renovate it by means of the manipulation and the montage in kaleidoscopic aesthetics. The new objects often tend to have nothing common with the originals. And deconstruction is more that a technical procedure in this case: "[...] Deconstruction itself never appears as a purely technical analysis tool, but always a kind of deconstructive-negative cognitive imperative postmodern sensibility" ${ }^{28}$. Photographers desire to deal with the city as a mechanism with no coherent structure, open for visual transformations. As a result the city or separate architectural objects become unrealistic, surreal, even mysterious.

\section{FINDINGS. CONCLUSION REMARKS}

Finalizing the paper I would like to posit a number of conclusions.

1. Kaleidoscope which was originally a toy, an entertainment, has been "adopted" by artists and photographers in the $20^{\text {th }}$ century as a serious tool to conduct experiments with form, structure, volume. The majority of experiments with the architecture as the subject date back to the early $21^{\text {st }}$ century that can be associated with the development of digital photographic techniques and software for image processing.

2. Balanced and at the same time unpredictable and uncontrolled chaos as the main principle of the organization of the kaleidoscopic image provides a special form of abstraction. The abstraction that is retreated into itself, that is built from the pieces of glass in case of a classical kaleidoscope and of the incidental elements of human environment in case of teleidoscope. Through multiple repetition and mirroring these elements loose their essence of concrete objects and become fragments of the kaleidoscopic hole.

3. The anticipation of kaleidoscopic image structure might be found in nature. Architectural morphogenesis demonstrates similarity with genetic traits of morphogenesis in biology and crystallography. Thereby human-made symmetrical centered kaleidoscopic structures are not bio generated but artificially generated by means of a technical device. And at the same time they have analogues in nature. A bit paradoxical, but it is so. 
4. What is particularly interesting is the fact that almost all projects have a kind of prototype except the kaleidoscope by itself. We might observe several allusions to Maurits Cornelis Escher who created impossible architectural and non-architectural visual labirints in his graphics. Some of the authors such as Mattia Mognetti, Andrey Chezin were inspired by Escher's drawings. The second visual allusion is Rorschach's spot strategy which is touched upon mirrored images (some of them are kaleidoscope like as well). Individual photographers refer to other photographers. The special case is "Inception" imitation. Thereby the kaleidoscope is much more an instrument but not a source of visual inspiration.

5. Technically there is a variety of modes of achieving the kaleidoscope effect: digital manipulations (majority of projects), mask filters (Andrey Chegin), fish-eye lenses (Mohammad Domiri). The first and the second techniques in one way or another implement the deconstruction process.

6. Architectural hybrids created by kaleidoscopic photography eradicate their Earth gravity - they are presented as objects flying in the sky or beeing in some nowhere, in vacuum. For now it seems to be a total, allout of utopia if we are talking about Earth-based architecture.

7. Today's urban space is quite a stable structure. It demonstrates the ability to change and for rapid transformation at the level of urban software, but not at the level of urban hardware. Perhaps the future cities will be arranged a little bit differently and will be more mobile, agile, fluid at the level of urban hardware as well. As far as these claims are utopian, future might surprise us. www.mattiamognetti.com/97244/718297/portfolio/istigkeit. 
Mandala has kaleidoscopic like structure and by many kaleidoscopic artists is perceived as the source of inspiration. Janice Chesnik: "It represents continuity, beauty, and serenity, but holding the possibility of something new and exciting with every change." - Cozy Baker, Kaleidoscopes: Wonders of Wonder (C\&T Publishing, 1999), 37.

Maria Romakina, Interview with Borbála Sütő-Nagy, 07.07.2015. Personal archive of Maria Romakina.

Cory Stevens, Portfolio. Personal website of Cory Stevens, accessed may 30, 2015, www. corystevens.ca.

Liz Stinson, Photog Transforms Oddball Buildings Into Dizzying Kaleidoscopic Images. Wired, published may 9, 2013, accessed may 18, 2015, http://www.wired.com/2013/09/these-dizzyingkaleidoscope-images-are-actually-buildings/.

Maria Romakina, Interview with Cory Stevens, 07.07.2015. Personal archive of Maria Romakina. Iran's remarkable Mosques: Mohammed Domiri. Arch2o, accessed may 30, 2015, - http://www. arch2o.com/iran-s-remarkable-mosques-mohammed-domiri/.

Stéphane Laniray Tokyo Architecture. Actuphoto, published august 12, 2012, accessed may 18, 2015, http://fr.actuphoto.com/8497-stephane-laniray-tokyo-architecture.html.

Demetrios Gkiouzelis, The MIRRORS iPhoneography Project of Hellopanos. Yatzer, published december 16, 2012, accessed may 30, 2015, http://yatzer.com/mirrors-iphone-hellopanos.

Virginio Favale, Portfolio. Personal website of Virginio Favale, accessed may 30, 2015, http:// www.virginiofavale.com/.

Andrey Chegin, City-cross, 1996. // Чежин, Андрей. Город-крест, 1996. Personal website of Andrey Chegin, accessed may 30, 2015, http://chegin.com/ru/62/.

Andrey Chegin, From the series "Escher's Space”. // Чежин, Андрей. Из серии “Пространство Эшера", 1996. Personal website of Andrey Chegin, accessed may 30, 2015, http://chegin.com/ ru/63-prostranstvo-eshera/.

Sergey Gureev. Andrey Chegin - master of contemporary Russian photography. // Гуреев, Сергей. Андрей Чежин - мастер современной Российской фотографии. Rasfokus.ru // Расфокус, published march 1, 2013, accessed may 30, 2015, http://rasfokus.ru/blogs/sg-blog/andrei-chezhinmaster-sovremenoi-rosiiskoi-fotografi.html.

Ben Thomas, Accession. Personal website of Ben Thomas, accessed april 28, 2015, http:// benthomas.net.au/accessionseries/.

Maria Romakina, Interview with Ben Thomas, 06.07.2015. Personal archive of Maria Romakina Asami Novak, Get Lost in Photographer Palla's Kaleidoscopic Images of Japanese Cityscapes. Wired magazine: Issue 15.12, published november 27, 2007, accessed april 28, 2015, http:// archive.wired.com/culture/art/magazine/15-12/pl_arts.

Maria Romakina, Interview with Kazuhiko Kawahara, 06.07.2015. Personal archive of Maria Romakina.

Simon Gardiner, Upside Town I, Upside Town II. Personal website of Simon Gardiner, accessed april 28, 2015, http://www.simongardiner.com.

Nickolas Kennedy Sitton's Twisted Series. Magical Urbanism, accessed april 28, 2015, http:// www.magicalurbanism.com/archives/5669.

Ilia Ilyin, Poststructuralism. Deconstruction. Postmodernism (Moscow: Intrada, 1996),177. // Илья Ильин, Постструктурализм. Деконструкиия. Постмодернизм (Москва: Интрада, 1996), 177. 
Antliff, Mark, Klein, Scott.W. Vorticism: New Perspectives. Oxford University Press, 2013.

Baker, Cozy. Kaleidoscopes: Wonders of Wonder. C\&T Publishing, 1999.

Chegin, Andrey. City-cross, 1996. // Чежин, Андрей. Город-крест, 1996. Personal website of Andrey Chegin, accessed May 30, 2015, http://chegin.com/ru/62/

Chegin, Andrey. From the series "Escher's Space”. // Чежин, Андрей. Из серии “Пространство Эшера", 1996. Personal website of Andrey Chegin, accessed May 30, 2015, http://chegin. com/ru/63-prostranstvo-eshera/

Esposito, Francesca. Architecture of the unconscious: Mattia Mognetti. Domus, published 26 March 2013, accessed May 18, 2015, http://www.domusweb.it/en/photoessays/2013/03/26/architecture-of-the-unconscious.html

Favale, Virginio. Portfolio. Personal website of Virginio Favale, accessed May 30, 2015, http:// www.virginiofavale.com/

Gardiner, Simon. Upside Town I, Upside Town II. Personal website of Simon Gardiner, accessed April 28, 2015, http://www.simongardiner.com

Gkiouzelis, Demetrios. The MIRRORS iPhoneography Project of Hellopanos. Yatzer, published december 16, 2012, accessed May 30, 2015, http://yatzer.com/mirrors-iphone-hellopanos

Gureev, Sergey. Andrey Chegin - master of contemporary Russian photography. // Гуреев, Сергей. Андрей Чежин - мастер современной Российской фотографии. Rasfokus.ru // Расфокус, published march 1, 2013, accessed May 30, 2015, http://rasfokus.ru/blogs/sgblog/andrei-chezhin-master-sovremenoi-rosiiskoi-fotografi.html

Güner, Fisan. Visions of Urban Apocalypse. The Tretyakov Gallery, \#3, 2011: 100-107.

Haeckel, Ernst. Art forms in nature. Prestel, 2008.

Ilyin, Ilia. Poststructuralism. Deconstruction. Postmodernism. Moscow: Intrada, 1996. // Ильин, Илья. Постструктурализм. Деконструкция. Постмодернизм. Москва: Интрада, 1996.

Iran's remarkable Mosques: Mohammed Domiri. Arch2o, accessed May 30, 2015, http://www. arch2o.com/iran-s-remarkable-mosques-mohammed-domiri/

Mognetti, Mattia. Istigkeit. Personal website of Mattia Mognetti, accessed May 18, 2015, http://www.mattiamognetti.com/97244/718297/portfolio/istigkeit

Nickolas Kennedy Sitton's Twisted Series. Magical Urbanism, accessed April 28, 2015, http:// www.magicalurbanism.com/archives/5669

Novak, Asami. Get Lost in Photographer Palla's Kaleidoscopic Images of Japanese Cityscapes. Wired magazine: Issue 15.12, published november 27, 2007, accessed April 28, 2015, http:// archive.wired.com/culture/art/magazine/15-12/pl_arts

Romakina, Maria. Interview with Ben Thomas, 06.07.2015. Personal archive of Maria Romakina.

Romakina, Maria. Interview with Borbála Sütő-Nagy, 07.07.2015. Personal archive of Maria Romakina.

Romakina, Maria. Interview with Cory Stevens, 07.07.2015. Personal archive of Maria Romakina.

Romakina, Maria. Interview with Kazuhiko Kawahara, 06.07.2015. Personal archive of Maria Romakina.

Romakina, Maria. Interview with Mattia Mognetti, 10.07.2015. Personal archive of Maria Romakina.

Sontag, Susan. On photography. Pinguin books, 2008.

Stinson, Liz. Photog Transforms Oddball Buildings Into Dizzying Kaleidoscopic Images. Wired, published may 9, 2013, accessed May 18, 2015, http://www.wired.com/2013/09/thesedizzying-kaleidoscope-images-are-actually-buildings/

Stéphane Laniray Tokyo Architecture. Actuphoto, published august 12, 2012, accessed May 18, 2015, http://fr.actuphoto.com/8497-stephane-laniray-tokyo-architecture.html

Stevens, Cory. Portfolio. Personal website of Cory Stevens, accessed May 30, 2015, www. corystevens.ca 
Sütő-Nagy, Borbála. Kaleidoscope. Bēhance, published may 30, 2012, accessed May 30, 2015, https://www.behance.net/gallery/4072191/Kaleidoscope

Thomas, Ben. Accession. Personal website of Ben Thomas, accessed april 28, 2015, http:// benthomas.net.au/accessionseries/

Vortograph. Enciclopaedia Brittanica, accessed april 20, 2015, http://www.britannica.com/ EBchecked/topic/632963/vortograph 


\section{"NEPRIJATELJ NAŠEG DOBA": GODAROVA ESTETIKA SAVREMENOSTI NASUPROT SINHRONIZACIJI \\ Jakob Lund}

Pred kraj svog filmskog eseja Histoire (s) du cinema Žan-Luk Godard sebe naziva 'neprijateljem našeg doba', 'totalitarizma sadašnjosti primenjenog mehanički svakim danom sve više represivno na planetarnom nivou.' Članak gleda Histoire(s) du cinema (1988-1998) kao 'oblik razmišljanja' koji pokušava da se odupre sinhronizaciji, standardizacionom vremenu globalnog kapitala, sveprisutnoj uniformnosti svetske super-sadašnjosti, koje donosi današnja televizijska i digitalna komunikacija, koja preti da trivijalizuje različite procese memorije i istorije i umetnosti i kulture uopšte. Prema filozofu Bernardu Štigleru, završna faza kapitalizma je kontrola i sinhronizacija onoga što je bivši direktor TF1 Patrick Le Lai nazivao 'dostupno vreme mozga'. U radu se ističe da se rad Godarda protivi ovoj kontroli i sinhronizaciji naših umova kroz estetiku savremenosti. Argument je zasnovan na razvoju teorijskog okvira koji kombinuje najnovije teorije savremenosti sa teorijama sliko-politike. Fokusirajući se na povezanost pojedinca, društvene i medijske sredine, rad će se baviti Godardovo, je sliko-političkim stvaranjem vremenske savremenosti kroz montažu snimaka starih filmova i filmskih žurnala, fotografija, fotografija bez pokreta, snimaka slika, novih snimka, reklama, muzika, zvuka i snimaka govora, tekstualnih citata, priča i komentara.

KLJUČNE REČI: SAVREMENOST, SLIKO-POLITIKA, TELEVIZIJA, VREMENSKO ISKUSTVO, GODARD

\section{ARHITEKTONSKI HIBRIDI NA KALEIDOSKOPSKOJ FOTOGRAFIJI \\ Maria Romakina}

Ovaj rad se fokusira na temu koja je na neki način raskrsnica između dve oblasti: fotografija i arhitektonska morfogeneza. Posebno interesovanje članka je savremena fotografska tendencija da se istraži kaleidoskopska tehnika i estetika u odnosu na arhitektonske objekte i urbane sredine. Paradoksalno ovo su fotografi koji istražuju ovu posebnu vrstu morfogeneze arhitektonske forme. Međutim, neki od njih su originalno arhitekte. Obraćajući pažnju na istorijske i evolutivne aspekte kaleidoskopske slike u 19. veku i kaleidoskopske fotografske prakse američkog umetnika Alvina Langdona Koburna i njegovih sledbenika u 20. i 21. veku, rad ima za cilj da analizira potencijal fotografije u razvoju arhitektonske forme primerima projekta Matije Mogneti, Borbale Suto-Nagi, Korija Stevensa, Stefana Laniraia, Panosa Papanagiotua, Andreja Čegina, Muhameda Domirija i onih fotografa koji su inspirisani radom kamere iz filma 'Inception' - Ben Tomas, Kazuhiko Kavahara, Simon Gardiner, Nikolas Kenedi Siton.

KLJUČNE REČI: KALEIDOSKOP, ARHITEKTURA, APSTRAKCIJA, HIBRIDNA STRUKTURA, FOTOGRAFIJA, VORTOGRAF ALVIN LANGDON COBURN, MAURITS CORNELIS ESCHER, FILM "INCEPTION"

SINEMATSKI ASPEKT ARHITEKTURE:

\section{ULOGA VREMENA U DISKUSIJI O ALTERNATIVNIM ARHITEKTONSKIM STRATEGIJAMA}

\section{Katarina Anđelković}

U potrazi za načinima za prevazilaženje negativnih konotacija primene karakteristično tradicionalnih metoda prakse u trenutnom regulisanju prostorno-vizuelnih parametara urbanog okruženja, krećemo se ka razmatranju alternativnoj 'arhitekturi odnosa'. Rad razjašnjava kako film može ponuditi alternativno mesto u arhitekturi, gde su urbani prostori smišljeni i dizajnirani u bližem odnosu sa potencijalima filma da manipulišu realnost, promene način percepcije, daju viziju i rekonstruišu nesvesne impulse metropole. Eksperimentalni dizajni pokazuju kako odzvanjajući zapisi prostora, vremena i kretanja kroz prostor može simulisati impuls mapiranja koji inspiriše alternativni pristup dizajniranju prostora. Moj pristup se oslanja na različite proizvodne platforme znanja da detektuje vremensko srodstvo između filmskog i stvarnog prostora. Oni su ovde navedeni u kontekstu postmodernih diskusija da otkriju novu interakcijsku tačku između filma i arhitekture, u cilju podrške režima zasnovanih na vremenu prijema arhitektonskih i urbanističkih ideja. 